\title{
Influencia de los aditivos de molienda de clínker en las características intrínsecas del cemento y en el comportamiento de morteros
}

\section{Influence of clinker grinding-aids on the intrinsic characteristics of cements and on the behaviour of mortars}

Fecha de recepción: 17-XII-02

Fecha de aceptación: 26-III-03

ESPAÑA

\section{RESUMEN}

En la fabricación de cemento portland es una práctica creciente la utilización de aditivos para optimizar el proceso de molienda. éstos quedan incorporados en el producto final y pueden influir sobre las características y propiedades del cemento, morteros y hormigones.

En este trabajo se presenta la evaluación de dos aditivos comerciales en la molienda conjunta de clinker de cemento portland y yeso comercial, tratados en un molino a bolas a escala de laboratorio, en forma comparativa con un cemento sin aditivo producido en forma equivalente.

Las conclusiones indican que los aditivos de molienda tienen influencia en las caracteristicas del cemento resultante, incrementando su superficie y modificando su microestructura y estado de agregacion; los morteros mejoran sus prestaciones mecánicas a todas las edades y se reduce la demanda de agua, aunque debe prestarse cuidado a las posibles interacciones con aditivos reductores de agua de hormigones.
D. REVUELTA, L. FERNÁNDEZ LUCO, F. DORREGO, M. P. DE LUXÁN

Instituto de Ciencias de la Construcción Eduardo Torroja (IETcc-CSIC). Madrid 
morteros y hormigones, ocasionando problemas de heterogeneidad de las mezclas.

El empleo de aditivos de molienda, o aditivos de proceso, como también se los designa, permite dar una solución conjunta a estos problemas, reduciendo el tiempo necesario para obtener una determinada finura, optimizando la distribución granulométrica del producto final y reduciendo la probabilidad de formación de grumos y en el ámbito internacional se realizan esfuerzos crecientes para su desarrollo, caracterización e identificación (1-2).

Evidentemente, el empleo de aditivos de molienda está restringido a los productores de cemento, por lo que sus características, propiedades y requisitos no están difundidos entre los usuarios, sean consumidores finales, ingenieros, arquitectos, constructores, elaboradores de hormigón, fabricantes de elementos premoldeados, etc. Sin embargo, hay evidencia experimental de investigaciones en ese sentido por parte de especialistas en tecnología de hormigones (3).

El objetivo de este trabajo se orienta a establecer algunas pautas que complementen la escasa información relativa al efecto del empleo del aditivos de molienda sobre las propiedades del cemento, morteros y hormigones.

\subsection{Principio de acción de los aditivos de molienda}

El proceso de molienda involucra la fragmentación y atrición de las partículas de clínker, así como atrición entre los cuerpos moledores y el revestimiento interno del molino. De esta forma, se generan cargas electrostáticas en los finos del cemento y esto conduce a la aglomeración de partículas.

Los aditivos de molienda reducen las cargas electrostáticas de las partículas de cemento, cuerpos moledores y revestimiento, contribuyendo a minimizar los fenómenos de aglomeración de partículas y aumentando la eficiencia del proceso de molienda. En forma análoga, la anulación de cargas superficiales en las partículas de cemento conduce a mejorar la movilidad del cemento en el silo y conductos de transporte, favoreciendo su transporte.

Básicamente, con la utilización de aditivos de molienda se mejora la eficiencia del molino, reduciendo los costes derivados de la molienda y la demanda de energía (4-6). En la Figura 1 se muestra que el consumo de energía en la molienda en molino horizontal es, considerado como proceso unitario, el más alto de los que integran un ciclo estándar de producción de cemento. the increase in energy costs, lead to a growing use of these admixtures, mainly in developed countries.

The use of grinding aids (also known as process admixtures) may solve both problems, since they reduce the time needed to obtain the required fineness, improving the particle-size distribution, reducing the risk of set packing, and improving the overall plant efficiency. There are increasing international efforts to develop, characterise and identify these admixtures (1-2).

Obviously, the use of grinding aids is limited to the cement producers; thus, end-users such as engineers, architects, or concrete producers have very little knowledge about the characteristics of these products, although some experimental research about its influence on concrete has been carried out (3).

This paper tries to make up for the lack of information about the influence of the grinding admixtures on the mechanical properties of cement, concrete and mortar.

\subsection{Working principle of grinding aids}

The grinding process involves fragmentation and attrition not only among clinker particles, but also the wear out of the grinding elements and the mill walls. Friction among particles produces static electricity that leads to agglomeration of the fine particles.

Grinding aids reduce the electrostatic charges of the cement particles, the grinding balls and the mill walls, thus they minimize the cluster formation and improve the grinding efficiency. Besides, the cancellation of the electrical charges provides better cement mobility, making transport in the ducts and silos much more easier.

Eventually, the use of grinding admixtures improves the mill efficiency and reduces the energy costs (4-6). Figure 1 shows how that the grinding process has the higher energy consumption of the whole cementproduction process. 


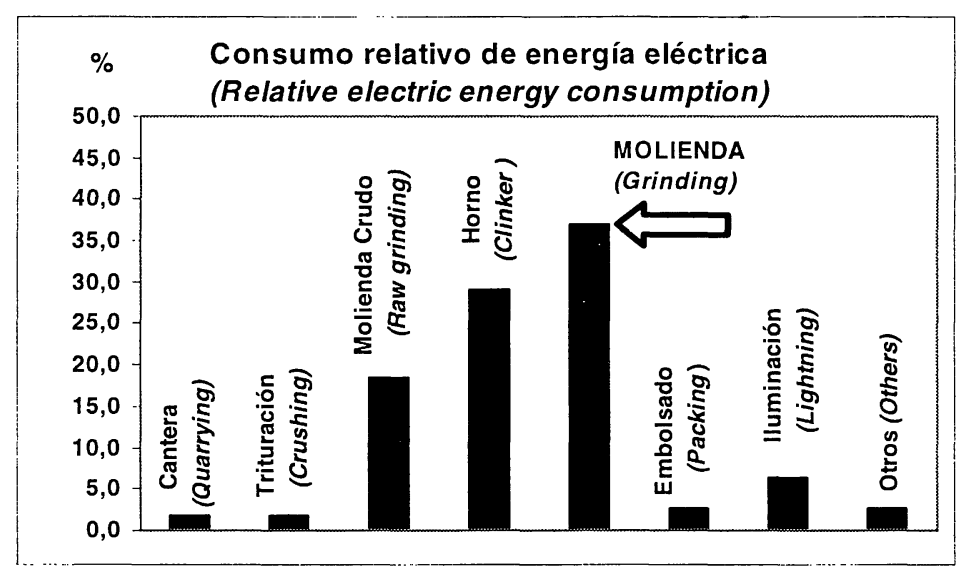

Figura 1.- Demandas relativas de energia eléctrica en el proceso de producción del cemento.

Figure 1.- Relative electricity consumption during cement production.

\subsection{Consideraciones normativas para el empleo de aditivos de molienda}

El empleo de aditivos de molienda está contemplado por la normativa, tanto europea (7), como norteamericana (8) e india (9), por citar solamente las más conocidas. A modo de ejemplo, la EN 197-1 considera a los aditivos de molienda como uno de los constituyentes del cemento, agrupándolo junto a otros productos tales como aditivos aireantes y colorantes.

La cantidad de aditivo de molienda se limita, en general, a valores reducidos, del orden del $1 \%$ con respecto al peso de cemento, pero las dosis habitualmente empleadas están muy por debajo de este límite.

La norma ASTM C 465-96 (8), a la que se refieren numerosos fabricantes de aditivo, establece condiciones rigurosas para los aditivos de molienda que se empleen en la producción de cementos hidráulicos. Sus principales requisitos, en lo relativo al efecto sobre las propiedades del cemento, se transcriben a continuación en la Tabla 1.

Si se analizan cuidadosamente estos requisitos, se observa que las limitaciones están orientadas a impedir una eventual mayor demanda de agua, mayor consumo de aditivo o una posible reducción de las propiedades mecánicas, pero no se hace mención alguna respecto a los beneficios potenciales.

En principio, dado que tos aditivos de molienda tienen por lo general propiedades tensioactivas, o de reducción de fuerzas superficiales entre partículas, su efecto sería justamente el opuesto: reducción de la tendencia a la formación de grumos, reducción la demanda de agua de pastas, hormigones y morteros, o incluso la incorporación de aire. Estas circunstancias se

\subsection{Existing regulations for the use of grinding aids}

The use of grinding admixtures is regulated in places like europe (7), U.S.A. (8) and india (9). For instance, the european standard EN 197-1 considers that the grinding aids are a constituent part of the cement, so they need a special treatment like other products as air entraining agents or colouring additions have.

The dosage of the grinding admixture is limited in the regulations to $1 \%$ maximum by cement weight. However; the usual dosages are far below that limit.

The american standard ASTM C 465-96 (8), the usual reference among the producers of grinding admixtures, establishes a number of specific requirements for grinding aids used in the manufacture of hydraulic cements. The principal properties affected by grinding admixtures that is necessary to monitor in cement according to ASTM C 465-96 are shown in Table 1.

Through observation of these requirements, it is concluded that the limitations focus on avoiding possible higher water demands, large admixture consumption or a reduction in the mechanical strength of the cement. However; the potential benefits are not identified.

Since the grinding admixtures have surfactant properties, reducing the attracting forces among particles, the effect is the reduction of cluster formation, reduction of water demand in paste, mortar and concrete, or air entraining. These effects improve the fresh properties of mortar and concrete (workability), but they may also produce an 
TABLA 1/TABLE 1

Esquema de requisitos establecidos por ASTM C 465-96

Grinding aids requirements according to ASTM C 465-96

\begin{tabular}{|c|c|}
\hline Propiedad/Propertie & Requisito/Requisite \\
\hline $\begin{array}{l}\text { Porcentaje de agua para pasta de consistencia normal. } \\
\text { Water demand to obtain normal consistency of cement. }\end{array}$ & $\begin{array}{l}<(\% \text { pasta de referencia }+1) \\
<(\% \text { control cement }+1)\end{array}$ \\
\hline $\begin{array}{l}\text { Demanda de agua para mortero de igual fluidez. } \\
\text { Water demand for mortars of standard consistency. }\end{array}$ & $\begin{array}{l}<(\% \text { mortero de referencia }+2) \\
<(\% \text { reference mortar }+2)\end{array}$ \\
\hline $\begin{array}{l}\text { Tiempo de fraguado en pasta de cemento. } \\
\text { Setting time of pastes by Vicat Needle Test. }\end{array}$ & $\begin{array}{l}<(\text { tiempo de referencia }+1 \mathrm{~h}) \text { ó }<1,5 \\
\text { (tiempo de referencia). } \\
<\text { control setting }+1 \text { hor }<1,5 \text { control } \\
\text { setting. }\end{array}$ \\
\hline $\begin{array}{l}\text { Expansión en autoclave, expresada como cambio porcentual de } \\
\text { longitud. Autoclaved expansion, as percentage of length change. }\end{array}$ & $\begin{array}{l}<(\text { expansión de referencia }+0,1) \\
<(\text { control expansion }+0,1)\end{array}$ \\
\hline $\begin{array}{l}\text { Resistencia a la compresión en mortero normalizado, a las edades } \\
\text { de } 1,3,7 \text { y } 28 \text { dias (cubos de } 50 \mathrm{~mm} \text { ). Compressive strength in } 50 \\
\text { mm mortar cube, at the age of } 1,3,7 \text { and } 28 \text { days. }\end{array}$ & $\begin{array}{l}>0,95 \text { (resistencia del cemento de } \\
\quad \text { referencia). } \\
>95 \% \text { control cement strength. }\end{array}$ \\
\hline $\begin{array}{l}\text { Contracción por secado (valor último), expresada en \%. } \\
\text { Ultimate drying shrinkage (\%, length by length). }\end{array}$ & $\begin{array}{l}<(\text { contracción de referencia }+0,025) \\
<(\text { reference shrinkage }+0,025)\end{array}$ \\
\hline $\begin{array}{l}\text { Resistencia a la compresión y flexión del hormigón, a cualquier } \\
\text { edad. } \\
\text { Concrete compressive and flexural strength, at any age. }\end{array}$ & $\begin{array}{l}>0,90 \text { (resistencia del hormigón con cemento } \\
\text { de referencia a esa edad). } \\
>0,9 \text { compressive or flexural strength of } \\
\text { concrete made with control cement. }\end{array}$ \\
\hline $\begin{array}{l}\text { Demanda de aditivo incorporador de aire en morteros, para obtener } \\
19 \pm 3 \% \text { de aire ocluido. Amount of air entraining admixture to } \\
\text { obtain } 19 \pm 3 \% \text { air in mortar. }\end{array}$ & $\begin{array}{l}<1,2 \text { demanda de aditivo correspondiente a } \\
\text { la referencia. } \\
<120 \% \text { of the amount of } A E A \text { for the mortar } \\
\text { made with control cement. }\end{array}$ \\
\hline
\end{tabular}

Nota: La referencia estará constituida por una pasta, mortero y hormigón equivalente, pero producido con el cemento de referencia, esto es, sin aditivo de molienda o adición mineral coadyuvante de molienda (adición de proceso). Note: the reference or control mix will be a paste, mortar or concrete produced with the control cement, using the same proportions but the grinding aid.

traducen en mejoras en las características de morteros y hormigones en el estado fresco e, incluso, en una mejora del comportamiento de morteros y hormigones frente a solicitaciones mecánicas, para situaciones que contemplen igual fluidez de las mezclas.

En este trabajo se presenta la evaluación de diversos aditivos comerciales en la molienda conjunta de clínker de cemento portland y yeso comercial, tratados en un molino a bolas a escala de laboratorio. Los ensayos se realizaron en forma comparativa con un cemento de referencia sin aditivos y con tiempos de molienda equivalente. El diseño del programa experimental está orientado tanto a evaluar la reducción de la demanda de agua y el incremento de resistencia de morteros y hormigones, como el efecto del empleo del aditivo sobre características particulares del cemento producido. improvement in the mechanical properties of the mortar and concrete when compared to mixes with the same workability but without admixtures.

This paper presents the results obtained from the evaluation of different available grinding aids used in a laboratory-scale ball mill where a clinker-gypsum mixture was ground. Tests were done on the resulting lab-ground cement, and compared to a product obtained by the same procedure but without the use of an admixture. The design of the experimental procedure was targeted to evaluate the reduction in water-demand, and the improvement in the mechanical strength of mortar and concrete, as well as some other effects on the produced cement due to the use of a grinding aid. 
Por ello, las determinaciones habituales se complementaron mediante el análisis por espectroscopía de absorción infrarroja, la determinación de las variaciones en la distribución de los tamaños de partícula mediante granulometría láser y las diferencias en la superficie específica Blaine.

La pluralidad de enfoques permite, no sólo obtener información vinculada con la respuesta final del producto sino también conocer las causas que conducen a tal comportamiento y realizar un análisis relativo al incremento en la eficiencia del proceso mismo de molienda.

Debe destacarse, sin embargo, que las condiciones reales de operación en un molino a escala real son significativamente diferentes, por lo que los resultados que se exponen deben considerarse de forma orientativa. Por este motivo, tanto el programa experimental como el análisis de los resultados se realizan en forma comparativa con referencia a un cemento patrón sin aditivo.

\section{PROGRAMA EXPERIMENTAL}

El programa experimental se basó en reproducir, a escala de laboratorio, un cemento patrón, constituido por clínker y yeso, mediante la molienda en molino de bolas, hasta obtener una finura y resistencia a la compresión equivalentes a las de cementos comerciales.

Mediante un proceso análogo, pero con el empleo de aditivos de molienda, identificados como Aditivo 1 y Aditivo 2, se obtienen los cementos a evaluar. A efectos comparativos, se mantuvo el mismo tiempo de molienda, por lo que las variaciones podrían manifestarse como cambios en la composición del cemento, la distribución de tamaños de partícula y la finura (evaluada por el residuo en tamiz de $45 \mu \mathrm{m}$ y permeametría Blaine).

Para evaluar la respuesta mecánica, se moldearon morteros empleando arena normalizada con escurrimiento o fluidez constante. De esta manera se evalúa la influencia del empleo de aditivos sobre la demanda de agua (efecto tensioactivo) y la incorporación de aire. Los resultados se expresan en forma relativa, a los efectos comparativos.

\subsection{Molienda de los cementos "con" y "sin" aditivos a escala de laboratorio}

El clínker y el yeso, suministrados por un fabricante de cemento fueron machacados previamente, hasta obtener un tamaño de 2 a $3 \mathrm{~mm}$, en forma separada para prevenir contaminaciones. Los finos generados se eliminaron por tamizado, a los efectos de moler únicamente las fracciones gruesas.

Para la molienda del clínker y el yeso se utilizó un molino de bolas cilíndrico con $530 \mathrm{~mm}$ de diámetro
Thus, the usual mechanical tests where completed with infrared spectroscopy, determination of grain sizes by means of laser grain-size analysis, and Blaine specific surface measurements.

The different techniques allow to obtain information about the final performance of the product, as well as the causes of that behaviour, determining the total increment in the efficiency of the grinding process.

However, it is fair to admit that the actual conditions in a real scale mill are significantly different to those of a lab mill, so the results hereby expressed are just an orientation. For this reason, comparison were done to a reference cement obtained in the same mill.

\section{EXPERIMENTAL PROGRAM}

The experimental program was based on the production of a control portland cement, made of portland cement clinker and gypsum, using a ball mill at laboratory scale. Mixing time was aimed to get a targeted fineness and a compressive strength similar to commercial portland cement.

The cements under testing were produced using the same process but Admixture 1 and Admixture 2 were used as grinding aids. Milling time was maintained and the eventual changes would appear as changes in cement composition, changes in particle size grading and fineness, measured by the residue retained by $45 \mu \mathrm{m}$ sieve and Blaine method.

Standard mortars with a given flow were prepared to assess the effect of the grinding aids on water demand, air entrainment and mechanical properties as well. The results are given on a comparative basis.

\subsection{Grinding "with" and "without" grinding aids at laboratory scale.}

Portland cement clinker and gypsum provided by a cement company were crushed up to 2 to $3 \mathrm{~mm}$ in diameter separately to avoid contamination. Fine particles were eliminated by dry-sieving to improve milling control by grinding only coarse particles.

Grinding was carried out by using a cylindrical ball mill, $530 \mathrm{~mm}$ internal diameter and $300 \mathrm{~mm}$ long, rotating at 
interno y $300 \mathrm{~mm}$ de longitud y una velocidad de rotación de 30 r.p.m., con carga de bolas de diámetros varios. La relación material-carga de bolas es de 1/10. A continuación se introduce el resto de la carga de bolas. Mediante ensayos exploratorios se determinó el tiempo de molienda necesario para obtener propiedades mecánicas equivalentes a las de un cemento comercial, que resultó ser aproximadamente 70 minutos.

La determinación de la resistencia a la flexión y compresión a la edad de 2 días para ambos cementos, tal como se muestra en la Tabla 2, indica que se consiguió el objetivo de obtener un cemento equivalente a uno comercial.

\subsection{Molienda con aditivo}

El proceso de molienda fue idéntico al descrito anteriormente, pero se añadió cada uno de los aditivos suministrados por el peticionario en forma individual, es decir, a dos muestras diferentes, en una proporción de $400 \mathrm{~g} / \mathrm{l}$, según las recomendaciones indicadas por el proveedor de los aditivos. Una vez transcurridos 70 minutos de molienda, se determinó la finura mediante el procedimiento del permeabilímetro Blaine y por tamizado húmedo del residuo sobre un tamiz de $45 \mu \mathrm{m}$ de abertura de malla. Los resultados obtenidos se indican en Tabla 3.

\section{RESULTADOS Y DISCUSIÓN}

\subsection{Molienda}

En las Figuras 2 y 3 se muestran las distribuciones de tamaño de partículas, obtenidas por granulometría láser.

Del análisis de los valores obtenidos por los diferentes métodos se concluye que el empleo de aditivos de molienda permite obtener un incremento de finura para un mismo tiempo de
$30 \mathrm{rev} / \mathrm{min}$. The ratio material to load was set at 1/10 and the load was constituted by different diameter balls. Grinding time required to achieve a mechanical performance comparable to commercial portland cements was set to $70 \mathrm{~min}$, by trial and error.

The results obtained from 2-days compressive and flexural testing of mortars (Table 2) indicate that the performance of the laboratory produced cement was equal or better than that of a commercial one, of medium strength grade (42.5 MPa).

\subsection{Grinding with grinding aids}

Grinding process was identical to the one described for the control cement, but grinding admixture 1 and 2 were added to identical samples, at a dosage of $400 \mathrm{~g} / \mathrm{l}$, according to the recommendations given by the admixtures producer. After 70 minutes of grinding, fineness was measured by the percentage retained in the $45 \mu \mathrm{m}$ sieve and Blaine Method. Results are given in Table 3.

\section{RESULTS AND DISCUSSION}

\subsection{Grinding}

Figures 2 and 3 show the particle size distribution measured by a laser granulometer.

By comparing the obtained results, it can be concluded that the use of grinding admixtures might lead to a higher fineness for a given grinding

TABLA 2/TABLE 2

Ensayos comparativos entre un cemento comercial CEM I 42,5 R y el cemento "patrón" obtenido por molienda en molino de bolas

Comparative tests between a commercial CEM I 42,5 R cement and the "reference cement" obtained at a laboratory ball mill.

\begin{tabular}{|c|c|c|}
\hline & $\begin{array}{c}\text { MR Flexión (Flexural } \\
\text { strength) } \\
(\mathrm{MPa})\end{array}$ & $\begin{array}{c}\text { Res. compresión } \\
\text { (Compressive strength) } \\
(\mathrm{MPa})\end{array}$ \\
\hline Patrón molienda (Reference) & 6,6 & 28,4 \\
\hline $\begin{array}{l}\text { Cemento comercial } \\
\text { (Commercial) }\end{array}$ & 6,1 & 23,4 \\
\hline
\end{tabular}


TABLA 3/TABLE 3

Eficiencia en la molienda mediante análisis comparado del retenido en tamiz de $45 \mu \mathrm{m}$ y la superficie específica Blaine

Gringind efficiency evaluated by the percentage retained on $45 \mu \mathrm{m}$ sieve and Blaine fineness.

\begin{tabular}{|c|c|c|}
\hline $\begin{array}{c}\text { Cemento patrón } \\
\text { Reference cement } \\
\text { Tiempo molienda (min) } \\
\text { Gringind time } \\
\text { aprox. } 70\end{array}$ & $\begin{array}{c}\text { sin aditivo } \\
\text { No-grinding admixture } \\
\% \text { Ret \# } 45 \mu \mathrm{m} \\
16 \\
\end{array}$ & $\begin{array}{c}\text { sin aditivo } \\
\text { No-grinding admixture } \\
\text { Superficie específica } \\
\text { Specific surface } \\
\left(\mathrm{cm}^{2} / \mathrm{g}\right) \\
4031 \\
\end{array}$ \\
\hline $\begin{array}{l}\text { Aditivo } 1 / \text { Admixture } 1 \\
\text { Tiempo molienda } \\
\text { Grinding time (min) } \\
\text { aprox. } 70\end{array}$ & $\begin{array}{l}\text { Dosis/Dosage } \\
\% \text { Ret \# } 45 \mu \mathrm{m}\end{array}$ & $\begin{array}{c}400 \mathrm{~g} / \mathrm{t} \\
\text { Superficie específica } \\
\text { Specific surface } \\
\left(\mathrm{cm}^{2} / \mathrm{g}\right) \\
4132\end{array}$ \\
\hline $\begin{array}{l}\text { Aditivo } 2 / \text { Admixture } 2 \\
\text { Tiempo molienda } \\
\text { Grinding time (min) } \\
\text { aprox. } 70\end{array}$ & $\begin{array}{l}\text { Dosis/Dosage } \\
\% \text { Ret \# } 45 \mu \mathrm{m}\end{array}$ & $\begin{array}{c}400 \mathrm{~g} / \mathrm{t} \\
\text { Superficie específica } \\
\text { Specific surface } \\
\left(\mathrm{cm}^{2} / \mathrm{g}\right) \\
4145\end{array}$ \\
\hline
\end{tabular}
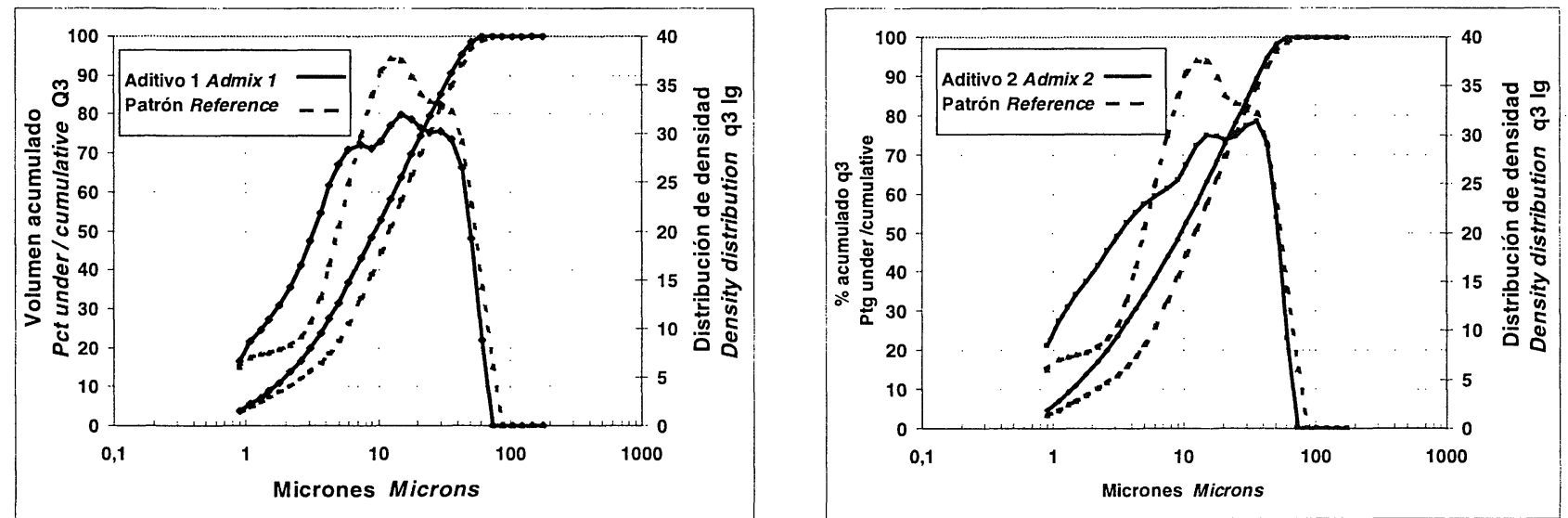

Figuras 2 y 3.- Granulometría láser para el cemento patrón y con Aditivos 1 y 2.

Figures 2 and 3.- Particle size-distribution (laser granulometer) for the reference cement and with Admixtres 1 and 2.

molienda. En condiciones industriales, se obtendría economía en el proceso de molienda.

\subsection{Aplicación de espectroscopía por absorción infrarroja}

La técnica de espectroscopía de absorción infrarroja (IR) se ha aplicado tanto al cemento anhidro, como al mismo cemento obtenido en condiciones similares pero incluyendo en la molienda uno de los aditivos objeto de estudio. Los espectros IR obtenidos se presentan en la Figura 4, donde se puede apreciar que no se observan diferencias, debidas a la incorporación del aditivo en la molienda, en las bandas de absorción relativas a los silicatos del clínker. time. It means a reduction in energy consumption in actual conditions.

\subsection{Infrared absorption spectroscopy application}

An infrared absorption spectroscopy technique was applied both to the anhydrous cement just after grinding with gypsum and to the cement produced in a similar manner with a grinding aid (Admixture 1). Their absorption spectra are shown in Figure 4, where no differences can be seen to de SC peaks associated to the use of the grinding admixture. 

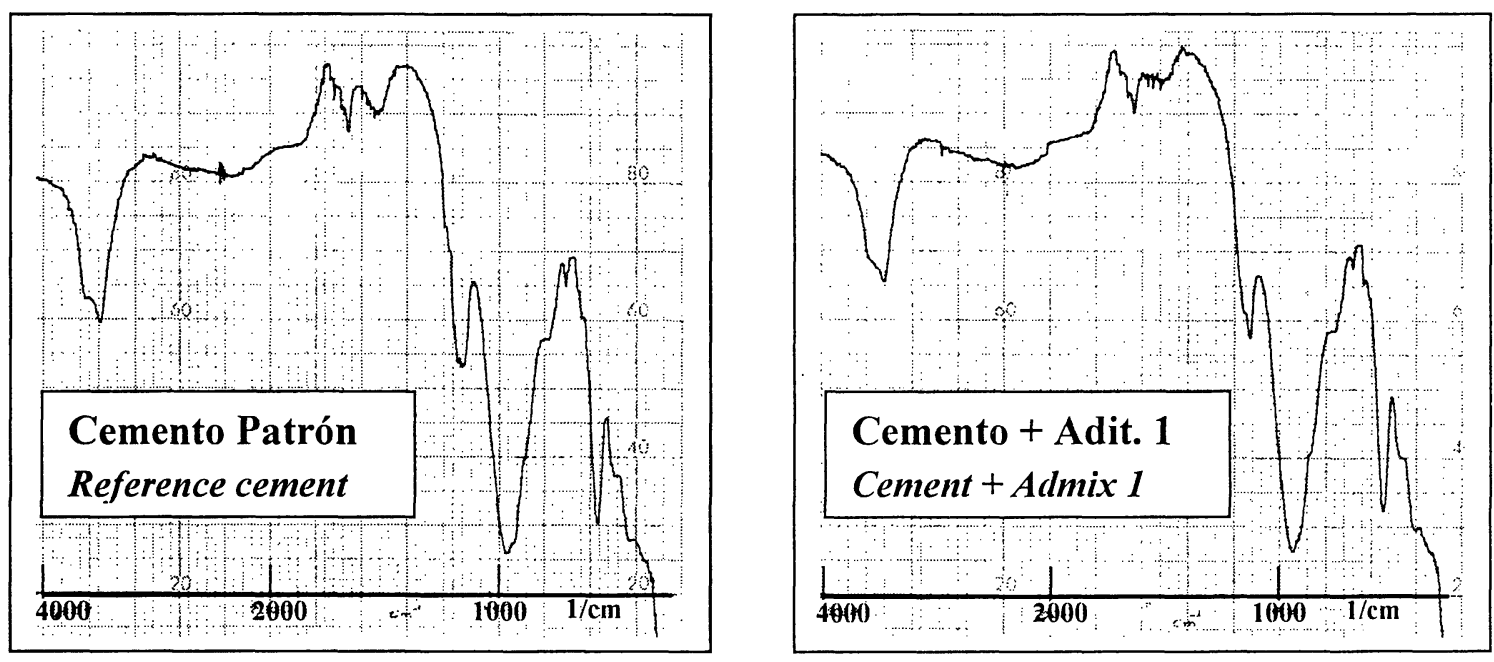

Figura 4.- Espectros de absorción infrarroja de dos cementos producidos.

Figure 4.- Infrared absorption spectra of two of the produced cements.

\subsection{Determinación de la resistencia mecánica}

Con las muestras de cemento obtenidas se moldearon probetas prismáticas de $40 \times 40 \times 160 \mathrm{~mm}$ de mortero normalizado, según UNE EN 196-1:1996, con una relación agua/cemento de 0,5 y una relación arena/ cemento de $3: 1$ en peso.

La normativa europea para la determinación de la resistencia de cementos no contempla la variación de la relación agua/cemento y prescinde de la determinación de la fluidez de la mezcla. Para contemplar esta característica, se evaluó complementariamente el escurrimiento y su interpretación se realiza en relación a una menor demanda de agua potencia.

Las probetas se sometieron a curado normalizado hasta las edades de ensayo, establecidas en 2 y 28 días. A esas edades se determinó la resistencia a la flexión y compresión. Los resultados obtenidos se muestran en la Tabla 4, donde también se indican los escurrimientos medidos para cada caso.

La determinación del contenido de aire no permitió encontrar diferencias significativas, pero esta particularidad se atribuye a que se utilizó el método gravimétrico, de menor sensibilidad.

\subsection{Evaluación comparada de resultados obtenidos}

La evaluación de los resultados obtenidos se efectúa, no sólo teniendo en cuenta los resultados individuales de finura y resistencia mecánica sino también analizando el conjunto de datos en forma relacionada. En principio, un incremento en la finura debería ir aparejado con una mejora en las propiedades mecánicas, pero la distribución de tamaño de partículas es determinante en esta relación.

En la Figura 5 se resumen los resultados de influencia del empleo de aditivos sobre la finura de molienda. Se

\subsection{Mechanical strength of mortars}

In order to determine the 2-day and 28-day strength of the cements, $40 \mathrm{~mm}$ by $40 \mathrm{~mm}$ by $160 \mathrm{~mm}$ prisms were cast using $a w / c=0.5$ and sand/cement $=3$ (both expresses as weight by weight), according to UNE EN 196-1996.

As the european standard does not take into account the actual flow of mortars but their w/c to be constant, the flow was measured as an indication of water demand: the smaller the flow, the lesser the water demand.

Mortar prisms were cured under standard conditions up to the age of testing. flexural and compressive strength results are summarised in Table 4, as long as the measured flow.

Air content was measured by the gravimetric technique at the fresh state, and no significant differences were found among the samples. This could be attributed to the low sensibility of this procedure.

\subsection{Evaluation of results on a comparative basis}

The evaluation of results is based not only on absolute values of fineness and mechanical strength but considering them as a whole. It might be guessed that the higher the fineness, the more the strength, but the particle size distribution might also play an important role.

The influence of the use of grinding admixtures on cement fineness are summarised in Figure 5. It should 
TABLA 4/TABLE 4

Resultados obtenidos en el ensayo de flexión y compresión sobre los morteros elaborados y ensayados según UNE

EN 196-1:1996 u escurrimiento según UNE EN 196-1:1996

Flow, Flexural and Compressive strength of mortar according to UNE EN 196-1:1996

\begin{tabular}{|l|c|cccc|}
\hline & & \multicolumn{2}{|c|}{2 días/2days } & \multicolumn{2}{c|}{28 días/28 days } \\
\cline { 3 - 6 } & $\begin{array}{c}\text { Escurrim. } \\
(\%)\end{array}$ & $\begin{array}{c}\text { Flexión } \\
\text { Flexural }\end{array}$ & $\begin{array}{c}\text { Compresión } \\
\text { Compressive }\end{array}$ & $\begin{array}{c}\text { Flexión } \\
\text { Flexural }\end{array}$ & $\begin{array}{c}\text { Compresión } \\
\text { Compressive }\end{array}$ \\
& Flow & $\mathrm{MPa}$ & $\mathrm{MPa}$ & $\mathrm{MPa}$ & $\mathrm{MPa}$ \\
\hline Patrón /Reference & 70 & 6,6 & 28,4 & 9,4 & 43,2 \\
Adit 1/Admixl & 75 & 6,9 & 30,9 & 10,3 & 50,6 \\
Adit 2/Admix2 & 77 & 7,0 & 31,1 & 9,1 & 50,4 \\
\hline
\end{tabular}

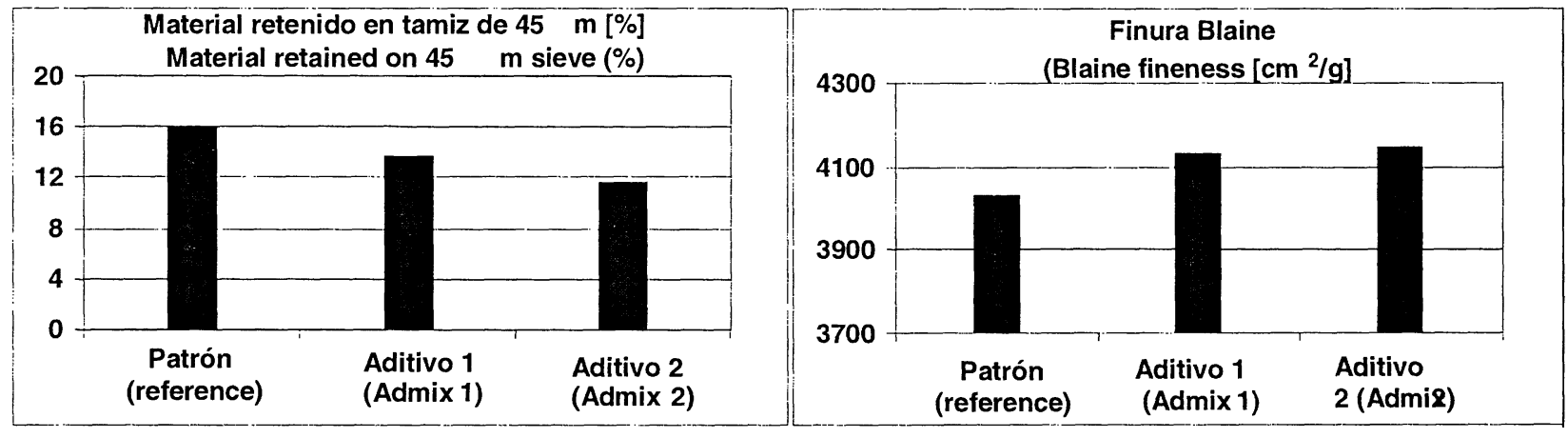

Figura 5.- Finura, por tamizado húmedo permeametría Blaine.

Figure 5.- Fineness determined by Blaine permeametry and wet-sieving on $45 \mu \mathrm{m}$ sieve.

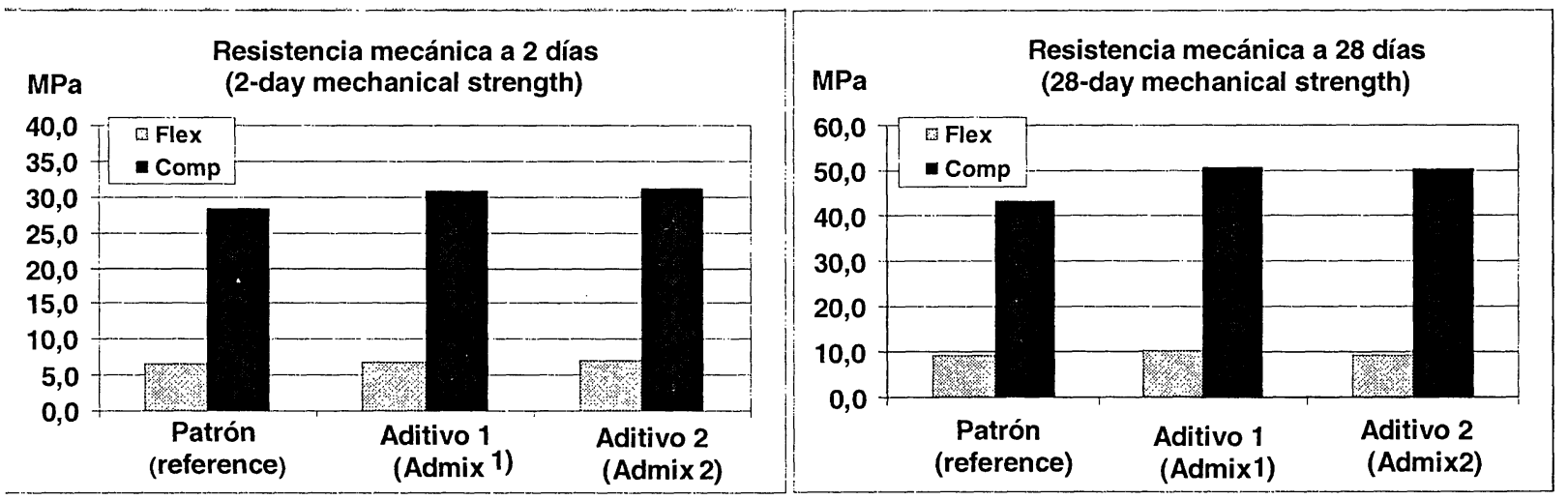

Figura 6.- Resistencia mecánica de mortero patrón y con aditivos a 2 y 28 días.

Figure 6.- Mechanical strength of reference mortar and admixture 2 and 28 days.

observa que, aunque los retenidos en el tamiz de $45 \mu \mathrm{m}$ de abertura de malla son marcadamente diferentes para los dos aditivos, ambos inferiores a los obtenidos con el cemento patrón, la superficie específica obtenida, para el cemento con uno u otro aditivo es prácticamente equivalente.

La Figura 6 muestra los resultados obtenidos, tanto a la edad de 2 como 28 días, en las determinaciones del comportamiento mecánico. Los valores de flexión son menos significativos que los correspondientes de compresión, dadas las características propias del ensayo be pointed out that while the \% of mass retained by $45 \mu \mathrm{m}$ sieve is different for both grinding aids, their Blaine values are almost identical. For any case, the fineness of the cement is increased when grinding admixtures are used.

Figure 6 shows the results of mechanical strength of mortars after standard curing. As flexural strength is 
y, de acuerdo con la normativa, no se emplean para la caracterización de cementos. Por esto, el análisis conjunto se centra en los valores de resistencia a la compresión.

\section{CONCLUSIONES}

La adición de aditivos de molienda añadidos en dosis de $400 \mathrm{~g} / \mathrm{t}$, permiten incrementar la finura del cemento obtenido para un mismo tiempo de molienda, en relación con los mismos materiales sin aditivo. Análogamente, se modifica la distribución de tamaños de partícula aunque no hay modificaciones en las características de composición del cemento, tal como se deduce de la espectrografía por infrarrojos.

La evaluación de las propiedades mecánicas, básicamente la resistencia a la compresión, muestra que la mayor finura se traduce en mayor resistencia, tanto a la edad de 2 días como a la de 28 días. Del análisis conjunto, se puede observar que la superficic específica presenta mejor correlación con la resistencia que el retenido en el tamiz de $45 \mu \mathrm{m}$.

Simultáneamente al efecto directo sobre la finura y granulometría del cemento, se observa una reducción leve en la demanda de agua, lo que permite, a su vez, mejorar la formulación de morteros y hormigones y compensar algún efecto potencia de incorporación intencional de aire.

Sin embargo, debe prestarse algún cuidado si se emplean aditivos incorporadores de aire o reductores de agua al elaborar morteros u hormigones, pues podría haber algún efecto sinérgico que potencie los efectos primarios o secundarios del aditivo adicionado. Esta situación puede plantearse incluso en el proceso de certificación de un aditivo comercial.

\section{AGRADECIMIENTOS}

Se agradece a la firma SIQSA el apoyo para este trabajo y el suministro de los aditivos de ayuda-molienda. not taken into account to characterise Portland cement, only compressive strength is considered.

\section{CONCLUSIONS}

The addition of grinding admixtures (grinding aids), at a dosage of $400 \mathrm{~g} / \mathrm{t}$ allow the fineness of cements to be increased for a given grinding time, as compared to the same materials without admixtures. The particle size distribution is modified as well, although the cement composition remains the same, as can be seen in the infrared spectra.

Based on the analysis of mechanical properties, mainly compressive strength, it can be concluded that the higher the fineness, the more the compressive strength at both, 2 and 28 days. Blaine fineness seems to be more correlated to compressive strength than the percentage of material retained by $45 \mu \mathrm{m}$ sieve.

Other than the effect of the grinding aids on the fineness and particle size grading, it can be seen that the water demand of mortars is slightly reduced. The lower water demand might compensate for the decrease in strength associated to air entrapment.

It must be pointed out that grinding aids might interfere with air-entraining-admixtures and water reducer admixtures for concrete, showing a synergic effect, which might enhance the primary or secondary effects of the concrete admixture. This situation might also interfere at a certification process for a commercial admixture for concrete.

\section{ACKNOWLEDGEMENTS}

With our most sincere thanks to SIQSA who gave support for this work and provided the grinding-aid admixtures.

\section{BIBLIOGRAFÍA}

(1) A. A. Jeknavorian, E. F. Barry, and F. Serafin "Determination of grinding aids in Portland Cement by pyrolysis gas chromatography mass spectrometry", Cement and Concrete Research, Vol. 28, No. 9, pp. 1335-1345 (1998).

(2) Ion Teoreanu, Graciela Guslicov, "Mechanisms and effects of additives from the dihydroxy-compound class on Portland Cement Grinding", Cement and Concrete Research 29, pp. 9-15 (1999).

(3) N. Bouzoubaa, L, M.H. Zhang, and V.M. Malhotra "Superplasticized Portland Cement: Production and Compressive Strength of Mortars and Concrete", Cement and Concrete Research, Vol 28, Nro. 12, pp 1783-1796 (1998).

(4) L. Sottili and D. Padovani "Effect of grinding aids in the cement industry, Part 1", ZKG International 53, Nro 10, pp. 568-575 (2000).

(5) L. Sottili and D. Padovani "Effect of grinding aids in the cement industry, Part 2", ZKG International 54, Nro 3, pp. 146-151 (2001).

(6) Rodney M. Edmeades and Peter Hewlett, Lea‘s Chemistry of Cement and Concrete, Capítulo 15, “Cement Admixtures" (2000).

(7) BS-prEN 206/BS 8500 «Concrete - Performance, production and conformity», august (1996)

(8) ASTM C 465-96: Standard Specification for Processing Additions for Use in the Manufacture of Hydraulic Cements. ASTM Standards, Vol. 15.05 (2002).

(9) BIS: Bureau of Indian Standards BIS Standards Conformity IS 269 (OPC 33), IS 8112 (OPC 43), IS 12269 (OPC 53), IS 1489 (PPC) and IS 1489 (PSC) (2001). 